\title{
Cyber Security and National Security Awareness Initiatives in Albania: A Synergy Approach
}

\author{
Hergis Jica \\ PhD Candidate on National Security, Defence Academy "Spiro Moisiu", Tirana Albania \\ Master in Economic Sciences Thessaloniki, Grecce \\ Master in Penal Law Sciences Tirana, Albania \\ E-mail: hergisjica@hotmail.com
}

\section{Doi:10.5901/mjss.2013.v4n10p614}

\section{Abstract}

Technological advances have changed the manner in which ordinary citizens conduct their daily activities. Many of these activities are carried out over the Internet. These include filling tax returns, online banking, job searching and general socializing. Increased bandwidth and proliferation of mobile phones with access to Internet in Albania imply increased access to Internet by the Albanian population. Such massive increased in access to Internet increases vulnerabilities to cyber crime and attacks and threatens the national security. As a result, Albania remains one of the countries that are targeted by phishing attacks. As a response, various entities engage in cyber security awareness initiatives and trainings with the aim to create cyber security awareness (CSA) among the citizens and the state institutions that operate in Albania. In the absence of a worthy national cyber security policy, however, these awareness initiatives and programmes are delivered through a variety of independent mechanisms. Various entities engage in cyber security awareness training each with its specific objectives and focus areas. It is argued in this paper that cyber security is complex and multi-faceted. No single solution can effectively address it and none of the participant actors can fight it by it's own. While the current means to create cyber security awareness does make impact, the fragmented and uncoordinated nature thereof have a potential to create its own dynamics. The focus of organizations and different institutional actors is, to deliver on their own objectives translates to some extent into the optimization of the behavior of individual entities as opposed to the optimization of the national cyber security awareness as a whole. This paper evaluates the extent to which the current cyber security awareness initiatives address the cyber security threats and risks. The assessment is based on the initiatives objectives, alignment of the program to the cyber threats, and the target audience.

Keywords: Albania, Security, Post Telecommunications, Cyber crime, Convention, Parliament, Attacks, International, Hacker, Technology, Information, Policy, Cyberspace, Cyber threats, Cyber criminals, Organizations, National, Virtual, State, Computer crimes.

\section{Albania before and after 1990}

Before 1990's, Albania had remained in an questionable era, comparing with the last technology epochs that had evolved the other countries. If we would compare these periods we wouldn't really be able to place properly within such an era, but we would very well express that we have known and used the phone. A meaningless expression for a world running so quickly towards the ongoing evolution, and in 1940 was introduced in the electronic age. In the 1990s computer was not known in Albanian offices as there were still being used typewriters and in the coming years, it would be exactly understood the backwardness in this area.

But let's take a historical overview of the development of telecommunications post in Albania, from its beginnings until now, where we'll definitely understand the stages passed by this important sector of the country. We will also see the time periods in which the evolution of technology began, that made possible the computer and internet spread, which are the basics that make up the virtual world and computer crimes.

\section{Post-telecommunications, and their development:}

Investigations made and PTT veterans' statements, show that some post offices existed in the Ottoman administration since 1878. In the late 19th and early 20th century, in Albania, operated even two cruise companie offices, the Austrian "Llojd" and the Italian "Puglia", which performed task postal services. But only after the declaration of independence on 
28 November 1912, Post- telecommunications service in Albania, marked its beginnings. Below are listed the most important historical events related to the performance and development of this important sector:

5 December 1912, The Provisional Government led by Ismail Qemali establishes the Ministry of Post Telegraph Telephones, Minister Lef Nosi.

5 May 1913, The first Albanian Post stamp is issued.

7 July 1913, The Provisional Government led by Ismail Qemali submits the request for membership to UPU and ITU, the process lasts 8 for years.

Year 1921, The first manual telephone central office with 200 numbers is installed.

Year 1922, The Albanian PTT administration is established at the Ministry of World Affairs. During that same year it accedes as member of UPU and ITU.

Year 1924, The Radio Station of the brand Marconi with a power of $3 \mathrm{~kW}$ is installed, providing telegraphic connection of Tirana with Belgrade, Zagreb and Vienna.

22 July 1924, The society "League of Albanian Post-Telegraphists" is founded. In its extraordinary congress held on 27 July-4 August 1924 it passed the relevant regulations which ensured the safety and protection of the rights of PTT employers.

Year 1930, A new automatic departmental telephone central with 150 numbers and cable network restricted only for the connection of ministries and other central institutions is added to Tirana.

During these years, Structure of services was $94.5 \%$ postal, with the postal correspondence with abroad dominating, 4.5\% telegraphic and only 1\% national telephone service. In PTT offices in cities, each Prefecture had a manual telephone central with 20-50 numbers, while some other cities had only one directory with 10 numbers connecting local authorities, and one Mors telegraph device each.

Year 1938, 68 offices \& postal agencies altogether. A period during which the Italian capital in our country increases, and the need for telephone calls especially towards Italy becomes indispensable. A short wave radio station providing telephony and telegraphy connections between Tirana and Rome is installed in Tirana.

Year 1942, These connections are interrupted as a result of bombings which completely destroy the repeater in Catalonia, Italy.

Occupation from Italy, Some lines, a few telephone centrals and other connection devices start to be built and installed serving the military machinery. Thus, the maritime cables Durres-Brindisi and Vlora-Bari were laid in Tirana, Durres, Elbasan, Shkodra and Vlora an telegraph devices of the brand Hughes are imposed which later get replaced by teletypes, other telephone lines are laid between prefectures, etc.

Year 1946, The telephone line Tirana-Peshkopia is constructed supporting a 3 telephone ditch for communications with other countries through Belgrade and Skopje, while the postal deliveries with abroad started to be made through Struga and Podgorica.

Year 1947, The first public telephone central is mounted in Tirana with 800 numbers; teletype devices are mounted in several districts of the country and the first course is opened with the best technicians of the time.

August 1947, The General Directorate of Post Telecommunications is established with a dependency on the Ministry of World Affairs and later on under the dependency of the Ministry of Communications.

Years 1949-1950, District lines continue to be built, "single" threads are replaced by copies thus significantly improving the telephone and telegraph services. The radio connection with Sofia is imposed through the $3 \mathrm{~kW}$ transmitter of Lapraka and the available receivers of the brand IMCA.

Year 1953, Automatic decadic telephone centrals are installed in Durres and Elbasan containing 150 and 100 numbers respectively.

Year 1954, A new service is added to the PTT, the newspaper subscription and distribution throughout the country with an average of 150 thousand copies per day. During the same year was built a small unit for repairing the telephone devices and centrals.

$\checkmark$ The PTT plant is established which supports the PTT development during those years until 1994, the year when its premises pass on to AMC.

Year 1955, Telephone networks' capacity increases by 2.8 times as compared with the year 1950, and about 4 times in the year 1960.

Years 1955-1960, 4000 numbers are added to the Tirana central and new automatic centrals are mounted in the main cities of the country like Shkoder, Gjirokaster, Korce, etc. a process which finishes in all cities and districts of the country in 1983. All these centrals were of the decadic system, electro mechanic technology. 
Year 1964, The first interurban cable interconnection Tirana-Durres is put into use, and was succeeded by other cable connections during the years 1970-1972 with Vlora, Lushnja, Fier, Berat, Elbasan and the residential areas between them.

Year 1965, The number of PTT offices reached 220 as compared to 68 that were before the liberation. Years 1965-1966, The radio receiver centre in Kamez and the radio transmitter centre in Cerrik are put at the disposal of the international interconnection, providing telephone and telegraph interconnection with all the countries around the world.

Year 1970, The direct connection of Tirana with all the district centers is realized by passing to the $12 \mathrm{Z12}$ telephone channels systems in the directions Tirana-Shkorder and Tirana-Korce. These equipments were of RFT production from Eastern Germany.

Year 1973, The direct phone calls of Tirana with other districts improve by means of the cable interconnection system (the 12-channel telephone equipment and the 16 and 18-channel telegraph equipment of this system were Chinese production whereas the interurban cable was symmetric).

Year 1973, Marks the start of the publication of the quarterly PTT Bulletin, which very clearly and accurately displays the achievements in staff trainings and qualifications in the country and abroad, the technical developments and technological improvements, extension and increase of the range of postal, telephone and telegraph services.

March 1973, General Directorate of Posts and Telecommunications passes under the dependency of the Council of Ministers, bringing about structural improvements in the whole pyramid, faster technical, technological and economic development of the system and most importantly a remarkable improvement of post and telegraph services to end users.

July 1973, Telephone and telegraph interconnection between Tirana and Rome is restored through the DurresBrindisi maritime coaxial cable, now repaired and partially replaced, and the new line with Greece (Tirana-GjirokasterIoannina) with 3 telephone channels is put into operation. The maritime radio connection passes under the authority of the General Directorate of Posts and Telecommunications which studies, designs and constructs in Durres powerful radio transmission and receiver centers, thus covering with telegraph services all the waters of the world and with phony up to the Red Sea and Baltic Sea.

September 1973, The first vocational full time courses are opened at the communications school in Durres.

September 1975, The central course of PTT opens in Tirana in all technical and services specialties.

December 3, 1973, The telephone connection of all the villages in the country is completed, a system mainly based on air lines and in some areas on cable network.

Year 1978, The first automatic telegraph central is set into operation, containing 200 numbers, crossbar technology, produced by Ericsson and ensured entrance of telegraph offices into Gentex automatic transmission, later to be upgraded by the telex electronic central of the French production Sagem.

Year 1979, The Law on PTT is approved for the first time.

Year 1981, The Centre for PTT Studies is established.

Year 1983

$\checkmark$ For the first time is realized the digital transmission in cable directions Tirana-Durres and Tirana-Elbasan (PCM cable systems $2 \times 300$ telephone channels +49 telegraph channels)

$\checkmark$ Interconnection with digital radio between Rinas, Kukes, B.Curri and Puka with Tirana is realized.

Year 1985, The National and International Transit Centre (DNT) is founded, including all telecommunications systems for national and international connections, thus enabling for the first time the division of the national and international network from the regional and urban network and the establishment of hierarchical network.

Year 1987

$\checkmark$ Starts the express postal service EMS.

$\checkmark$ The connection towards Italy is realized with radio Dajt-Correliano, a distance about $190 \mathrm{~km}$ with no repeater in between because of the sea, an achievement exceeding the limits determined in the different literatures for these kinds of connections over the sea.

April 10, 1989, The first interurban automatic telephone connection is realized between two cities Peshkopi and Bulqiza.

March 20, 1990, The first national and international transit central with 2000 gates is inaugurated, which was of digital technology, by the Italian company "Italtel", which connected Tirana, Durres, Elbasani and Korca to the automatic network, as well as through two radio systems with 120 channels each, one toward Greece and the other towards Italy, with all the countries worldwide. 
Year 1990, The first two digital local centrals, produced by "Italtel", are set into operation in Tirana (3000 numbers) and in Durres (2000 numbers).

Year 1990, Telecommunications network capacity reaches 37 thousand automatic numbers and 12 thousand manual numbers. The air and cable connections with symmetric an coaxial lines are predominant.

Year 1992

$\checkmark$ Telecommunications services separate from postal ones in accordance with international recommendations.

$\checkmark$ "Albanian Telecom" is established, as a state enterprise providing telecommunications services to fixed network.

$\checkmark$ "Albanian Post" is established, as a state enterprise providing postal services in 522 offices, as well as the General Directorate of Post-Telecommunications which functioned as the regulator of posts and telecommunications market.

$\checkmark$ The General Directorate of Post-Telegraph-Telephones is established, later to be called the General Directorate of Post-Telecommunications, in line with the technological trends of telecommunications service which as a result of automation had substantially reduced the demand for telegraph service.

Autumn 1992, The Albanian Government approves the Master Plan for the development of telecommunications in Albania, funded by Albanian Telecom, Albanian Government, European Bank for Reconstruction and Development (EBRD) and the Italian, Switzerland and Norwegian governments and under the leadership of the Finnish consulting company TELECON LTD, with the support of the Albanian Institute of Post Telecommunication, the Ministry of Transport and Communications and the Albanian Telecom. The Plan focused on the development of a hierarchical digital network which was to serve the most important inhabited centers and commercial areas in Albania and was based on the use of digital centrals in areas where the potential of demand for service exceeded the number of 10 thousand subscribers.

Year 1994

$\checkmark$ In the framework of the Master Plan, the national and international transit central with 8000 gates, of the digital technology Siemens, a Grand of the Swiss Government is installed in Tirana.

$\checkmark$ Albanian Telecom signs contracts with the company Alcatel for installing 66 thousand telephone numbers, and with the company Sirti for the construction of the interurban transmission network, based on the SDH technology with optical fibers and radio relay.

Year 1995, Marks the start of Internet in our country. The office of the United Nations Development Program (UNDP) in Tirana initiates the Internet project (free Internet for universities and academic institutions).

November 1995, The Assembly of Albania approves the law "On telecommunications in the Republic of Albania", with the assistance of the program PHARE. The Department of Post Telecommunications is established under the Council of Ministers.

Year 1996, The mobile service of the GSM standard starts for the first time in our country provided by AMC. Until the year 1999 this service was available only in Tirana, Durres and the Western Lowland and numbered about 15 thousand users.

Year 1996, Albanian Post starts for the first time the provisions of financial services.

Year 1996 and ongoing, The local digital centrals gradually start to be operated and the old electromagnetic centrals are removed. At the same time with new subscriptions the existing subscribers pass to the new urban networks. These processes are accompanied by the increase in the number of cities connected to the automatic system. Moreover, 4-channel radio systems are mounted with a view to improving the telephone and telegraph service in rural areas of the country, provided by the postal offices in about 200 communes.

Years 1996-1997, Mark a significant progress towards the improvement of the quality of service in international telephony, where apart from the transit central installed in 1994, a considerable assistance was provided by the increase in international lines, resulting from the engagement in two projects for the implementation of two national and international tracks, ADRIA 1, ADRIA 2 and TBL (Trans-Balkan-Line).

Year 1996, The Albanian segment is finished and set into operation, consisting of $520 \mathrm{~km}$ of maritime optical fibers of ADRIA 1 and ADRIA 2, a transmission system connecting Germany, Austria, Croatia, Albania and Greece.

Year 1997, The Albanian segment is finished and set into operation, a combination of optical fibers with radio systems of TBL, a transmission system connecting Italy, Albania, Macedonia, Bulgaria and Turkey.

Year 1997, The Internet initiative is supported by Soros Foundation which builds its own Internet network with the aim of providing this service free of charge for state institutions and non-governmental bodies. Because of legal barriers, the service is not provided in commercial terms until 1998. 
Year 1998, The law on telecommunications is amended, therefore finalizing the need for market development and the fulfillment of demands for services. This way, all the telecommunications services, apart from the telephone service (only Telephony in rural areas), are liberalized.

Year 1998, Telecommunications Regulatory Entity (TRE) starts functioning as a regulatory authority of the telecommunications market, a non-budgetary state body.

Year 1999

$\checkmark$ The Policy Paper of the Telecommunications Development is approved with Decision of Council of Ministers no. 288, dated 18/06/1999.

$\checkmark$ Albanian Post (Posta Shqiptare sh.a) and Albanian Telecom (Albtelecom sh.a) become joint stock companies.

September, Assembly of Albania approves the Law No.8530, dated 23/09/1999 "On postal services in the Republic of Albania", the first law regulating the postal service.

Year 2000

$\checkmark$ Doubles the capacity of the national and international transit central.

$\checkmark$ The contract signed with the German company Siemens enables the installment of local digital telephone centrals in other cities that were not part of the contract signed in 1994 with Alcatel and the installment of a new national and international transit central in Durres.

$\checkmark$ The Law No.8618, dated 14/06/2000 "On telecommunications in the Republic of Albania" is approved.

Year 2001

$\checkmark$ The connection Tirana-Mide-Pristina is set into operation through a radio relay system $34 \mathrm{Mbit} / \mathrm{s}$.

$\checkmark \quad$ All the undertakings performing postal activities are equipped with license or professional permission, thus enabling the market recognition, its regulation and the premises for development.

April-May

$\checkmark$ TRE drafts and implements the new Numbering Plan.

$\checkmark$ "National Radiofrequency Plan" is approved with Decision of the Council of Ministers no. 379, dated 31/05/2001.

August - The second GSM operator, Vodafone Albania gains the license.

$\checkmark$ International Internet access capacity is $4 \mathrm{Mbit} / \mathrm{s}$.

Year 2002

July, Postal operator ACS Albania starts operation with a network of 12 offices throughout the country, whereas other private postal operators provide their services only in the main cities.

September, The number of mobile users reaches 700000 and the area covered with service reaches $63 \%$ of the territory of the country and $85 \%$ of the population.

Year 2003

January, Urban, national and international telephony is liberalized.

November 25, TRE receives the Certificate of Observer at the Institution of European Standards of Telecommunications ETSI.

Year 2004

March, Albtelecom is granted the license for the third GSM operator: "Eagle Mobile"

$\checkmark$ International Internet access capacity reaches $12 \mathrm{Mbit} / \mathrm{s}$.

Year 2006

$\checkmark$ "The National Plan for the Implementation of the Stabilisation-Association Agreement" is approved with Decision of Council of Ministers.

$\checkmark$ Law No.8618, dated 14/6/2000 "On Telecommunications in the Republic of Albania" is amended.

May, International Internet access capacity reaches $68 \mathrm{Mbit} / \mathrm{s}$.

November, International Internet access capacity reaches $150 \mathrm{Mbit} / \mathrm{s}$.

Year 2007

$\checkmark$ The contract for the purchasing the shares of the company "Albtelecom" is ratified, thus passing $76 \%$ of Albtelecom shares to the ownership of CETEL "Çalik Enerji Telekomünikasyon Hizmetleri A.S".

$\checkmark$ Undertaking possessing a license for the provision of Internet are 32 altogether. Until the end of 2007, 8 new undertaking are granted the license.

$\checkmark$ The process of radiofrequency allocation is coordinated with international administrations for all applications such as: 
i. International coordination, with the administration of Macedonia, for the frequency band (380-390) and (390-400) MHz for emergency services.

ii. International radiofrequency coordination for fixed radio relay connections, complying with the requirements of AMC sh.a (5 connections) and Vodafone Albania sh.a (1 connection).

iii. Addressing the requirements for coordinating the frequencies allocated for satellite connections by the French and Italian administration.

$\checkmark$ The Mobile Monitoring Centre for performing measurements, determining the direction and detecting the location of transmitting stations operating in the $20 \mathrm{MHz}-3000 \mathrm{MHz}$ band is equipped.

October, International Internet access capacity reaches $300 \mathrm{Mbit} / \mathrm{s}$.

Year 2008

March, The third mobile telephony operator Eagle Mobile starts operation.

June, The Law no. 9918, dated 19/05/2008 "On Electronic Communications in the Republic of Albania" enters into force. This law brings Albania in line with the EU practice with regard to the telecommunications sector regulation.

October, The "main server" is transferred in Albania and the ccTLD.al domain starts functioning, enabling the full liberalization of the ".al" domain registration.

December, The number of mobile users by the end of 2008 is estimated to be approximately 2.7 million, meaning 85 mobile users per 100 inhabitants.

June, International Internet access capacity is $300 \mathrm{Mbit} / \mathrm{s}$.

Year 2009

June 26, Mobile 4 AL is granted the individual authorization becoming the fourth GSM operator.

May, National Frequency Plan is drafted and approved with DCM no. 479, dated 06/05/2009, which takes into consideration the developments trends following the year 2008 for the CEPT member countries, which also implements the latest recommendations and decisions of ITU, ETSI and the World Radio communications Conference.

By the end of 2009, there are 129 mobile phones per 100 inhabitants and an increase by $13 \%$ in telephone lines during the last 12 month. Charges of communication through mobile phones suffered considerable decrease as a result of a more intensive competition and the imposed regulation of tariffs. International Internet access in January of this year was $1200 \mathrm{Mbit} / \mathrm{s}$ and in December it reaches $6 \mathrm{Gbit} / \mathrm{s}$.

Year 2010

$\checkmark$ Regulation on .AL domain names regulation undergoes two essential changes consisting in granting the right to register a domain, apart from public and private persons, also to commercial physical person and to natural persons, as well as the reduction of the tariff to $2000 \mathrm{ALL}$ per two years.

$\checkmark$ The Policy Paper for the Electronic Communications in the Republic of Albania is approved with DCM No.322, dated 5/5/2010.

April , Approval of the "Regulation on number portability"

April, Approval of the "Radiofrequency Use Plan"

November, The fourth GSM operator "Plus Communications", enters the market commercially, a premise for the imposition of an efficient competition into the market.

December, Vodafone Albania is granted the individual authorization for the use of frequencies, for the provision for the first time of $3 \mathrm{G}$ services, as one of the most important objectives AKEP had for 2010, thus opening the way to the broadband wireless services market, towards accomplishing the Governments objectives for "Internet for all" and "Albania in the age of Internet".

December , International Internet access capacity reaches $14 \mathrm{Gbit} / \mathrm{s}$.

Year 2011

Continues the growing trend of the average use of telephone calls.

January, Vodafone Albania launches for the first time 3G services in Albania, and by the end of 2011 the number of subscribers using $3 \mathrm{G}$ services is about 280 thousand.

March, Approval of the regulation "On the General license for the provision of postal services", pursuant to which was realized the approach of undertakings' demands to transpose and gain general licenses for the provision of postal services.

May 2, The Centralized Reference Database for the Number Portability is inaugurated.

May, The first number is ported from one operator to another. By the end of 2011, 41000 numbers are ported.

June, Approval of the Regulation and Ordinance on the implementation of Carrier (Pre)Selection, enabling the end users of a telephone communications network to choose, by using the telephone line of the operator which they have a 
contract with, the provider of phone calls they consider as best for their needs, especially as regards the price and quality of phone calls.

September, AMC is granted the individual authorization for the provision of $3 \mathrm{G}$ standard services.

AKEP enables:

$\checkmark$ The on-line application system for the general authorization, based on the Web technology with a high level of information security, and ensures the increase of transparency and decrease of time limit for processing applications.

$\checkmark$ Storage system for operators' data on infrastructure in the on-line format WebGIS (ATLAS), which serves to keep accurate cartographic data in digital format for: the Optical Fiber Network installed throughout the territory of Albania; Radio Connection Network; GSM/3G system Network (location of BTS towers).

December , International Internet access capacity reaches $30 \mathrm{Gbit/s}$.

Year 2012

September 5 , The first number in fixed telephony is ported.

December 17, "Eagle Mobile" is granted the third individual authorization for the provision of $3 G$ services.

December , International Internet access capacity reaches $34 \mathrm{Gbit} / \mathrm{s}$.

But, for what reason we would need to see the post-telecommunications history? Are historical facts set forth above related to computer technology development in Albania? Do historical developments further influenced in posttelecommunications or are they just facts associated with this sector?. Let's take the questions in a row to give an explanation about them.

Post-telecommunication history in Albania makes the right connection between epochs passed by the world societies. This historic enables us to understand exactly over Albanian society through the pre-mechanical, mechanical, Electromechanical and Electronic epochs, despite of the slow technological development before 1990 and their gradual acceleration after 1990 and especially after 2000.

These historical facts have a direct connection with computer development in Albania, because Internet strands are indicated in our country, United Nations Development Program (UNDP), the office of Tirana, launches Internet project (Internet free of charge to universities and academic institutions). The Start of Internet is the first and basic step for the further development of computer systems and we can definitely say that we have the beginnings of computer crimes. Computer Crimes although unknown in these strands, we can't say they were missing, while in other countries of the world, they had begun to concretize in the virtual world aspects.

So, we can be convinced that post-telecommunication historical developments are facts that indicate directly with the further computer developments. Above historical facts constitute only one part of technological developments picture, also of those measures taken to prevent, documenting and combating cybercrime and cyber security.

Definitely, to complete this picture, it is necessary to see the history of legislation developments, concerning with computer works which showed that Albania was facing a real risk that increased every day. This risk can be well understood if we see that the main reasons for the adoption of laws dealing with computer crimes prevention and punishment of their perpetrators is due to an increased risk and the necessity to respond in time. Let's see legislative changes to determine the computer crime offenses and situation of Albania while these laws were adopted and followed.

\section{Cybercrime awareness and measures taken}

Given the ongoing technology developments and the increasing oncoming of our country towards developed countries, it was unavoidable to be concepted the cyber crime fact or "smart" crime termed. The first recorded case of cyber crime in our country was in 2008. In this case, the Albanian law enforcement institutions occurred in a difficult challenge that had to do with an unidentified crime as well as the fact that in our country there was no proper legal framework for the fight against these crimes. Although specific steps were made towards the area they were inadequate and shallow in terms of the legal framework.

Following the legal regulation that became necessary, due to new computer progress that was sweeping our country, it became necessary even issuing new laws contained in cyber field. Currently in our country, Convention "In cyber crime" was ratified by the Albanian Parliament with law No.8888, dated 25.04.2002 "On ratification of the "Convention on Cyber crime".

During 2008 and subsequently, there are taken series of legislative initiatives and created institutions such as: the Ministry for Innovation in Information and Communication Technology (MITIK), e-Albania (government portal), National Agency for Information Society (AKSHI), the Authority of Electronic and Postal Communications (AKEP), National 
Electronic Certification Authority (AKCE), Protik (ICT resurce center), Computer crime Division at the General Directorate of State Police, etc., which are fully committed to completing the legal framework and regulation of direct and indirect relationships between state institutions with each other and between them and private institutions and citizens. In January 2013, USAID organized a closing ceremony for Cyber Security Programme in Albania, a two-year initiative that helped to increase the capacity of the Albanian government to prevent and respond to cyber incidents. As a result of this support, Albania has already raised Cyber Incident Response Agency, "ALCIRT", a new structure that will work to protect cyber systems from natural disasters and cyberattacks. Also strategies of these institutions are focused on creating new spaces for technological development and the prevention and combating of cyber crimes that are increasingly more frequent.

But besides creating new institutions and other institutions, have generally realized the importance of being a participating factor in this broad national initiative and this for the fact that the development in this field is in it's fastest paces.

If we notice the amendments, laws or decisions that are recently adopted, we'll notice that their flux is multiplied after 2008 showing a very large predisposition in this direction. Some of these are as follows:

$\checkmark$ Law No.9859, dated 21.1.2008 for some amendments to Law No.7895, dated 27.1.1995 "Criminal Code of the Republic of Albania', as amended.

$\checkmark$ Law No.10023, dated 27.11.2008 for some amendments to Law No.7895, dated 27.1.1995 "Criminal Code of the Republic of Albania", amended, the Criminal Code amendments by Law No.9859 dated 21.1.2008 and by Law No.10023 dated 27.11.2008 made possible full reflection on the Convention of Cybercrime requirements.

$\checkmark$ The new law "On electronic communications" was approved on May 19, 2008 by the Parliament. This law is designed in accordance with European Union directives (package of 2002).

$\checkmark$ Law No.10054, dated 29.12.2008 "On some amendments to the code of criminal procedure."

$\checkmark$ Law on the Protection of Personal Data compiled in accordance with Directive Dir.95/46/EC. (Law No.9887, dated 10.03.2008 "On protection of personal data").

$\checkmark$ Law No.10273, dated 29.04.2010 "On electronic document".

$\checkmark$ Decision of the Council of Ministers No.945, dated 02.11.2012 "On approval of the Regulation" System Administration of database state".

$\checkmark$ Direction No.1, dated 31.12.2012, of the Minister for ITIK For the certification of the copy paper electronic documents from public institutions.

$\checkmark$ Law No.9918, dated 19.5.2008 "On electronic communications in the Republic of Albania".

$\checkmark$ Document for Electronic Communications Policies in the Republic of Albania, approved by the Council of Ministers No.322, dated 05.05.2010 "On approval of the Document of Electronic Communications Policy of the Republic of Albania".

$\checkmark$ Decision of the Council of Ministers No.303, dated 31.03.2011"On establishment of Information and Communication Technology Units in the line ministries and their subordinate".

$\checkmark$ Law No.9880, dated 25.02.2008, "On electronic signature".

$\checkmark$ Decision of the Council of Ministers No.525, dated 13.05.2009, "Rules for electronic signature".

$\checkmark$ Law No.9887, dated 10.03.2008, "On Personal Data Protection".

$\checkmark$ Law No.10128, dated 11.05.2009, "On electronic commerce".

$\checkmark$ Law No.10273, dated 29.04.2010 "On Electronic Document".

$\checkmark$ Decision of the Council of Ministers No.248, dated 27.04.2007, "On the establishment of the National Agency for Information Society", changed with, Decision No.837, dated 29.07.2009, Decision No.28, dated 20.01.2010, Decision No.26, dated 11.01.2012, Decision No.34, dated 01.31.2013.

$\checkmark$ Decision of the Council of Ministers No.723, dated 01.09.2010 "On the design, implementation and operation of information systems".

$\checkmark$ Law No.10325, dated 23.09.2010, "On the Database State".

$\checkmark$ Decision of the Council of Ministers No.961, dated 24.11.2010, "On the determination of the authority of the regulatory coordinating state databases".

$\checkmark$ Decision of the Council of Ministers No.1041, dated 14.10.2009, "On the passage of the National Electronic Certification (AKCE) to the Minister of State dependence".

$\checkmark$ Prime Minister Order No.86, dated 11.07.2008 "On approval of the organizational and structure of AKCE. 
$\checkmark$ Decision of the Council of Ministers No.1009, dated 10.12.2010 for determination of the contracting authority for the concession of the National Network Broadband in the Republic of Albania (National Broadband Network).

$\checkmark$ Prime Minister Order, No.119, dated 02.06.2010, "On the establishment of the cross-institutional working group, for the coordinating work and development of the National Network Broadband (National Broadband Backbone).

$\checkmark$ Prime Minister Order, No.124, dated 09.06.2010 "On establishment of the advisory group" National Forum for Digital Albania".

$\checkmark$ Decision of the Commissioner for Personal Data Protection No.1, dated 04.03.2010 on "Determination of the detailed rules for the provision of personal data".

$\checkmark$ Instruction of the Commissioner for Personal Data Protection No.4, dated 16.03.2010 for "Taking security measures of personal data security in the field of education".

$\checkmark$ Document of the Establishment of National Infrastructure of Geospatial Data (NSDI) policies, adopted by the Council of Ministers No.144, dated 22.02.2012 "On approval of the Policy Document" For the creation of the National Infrastructure of Geospatial Data".

$\checkmark$ Law No.72/2012 "On the organization and functioning of the national infrastructure of geospatial information in the Republic of Albania", promulgated by Decree No.7721, dated 20.07.2012 of the President of the Republic of Albania".

$\checkmark$ Directive 1999/93/EC, "For Electronic signatures".

$\checkmark$ Directive 2000/709/EC, "For Testing and Confirmation Body."

As above, they're only a part of the normative acts which support the development of computer technology and create a proper legal framework for the prevention and striking structures of cybercrime. Despite the changes and amendments of laws and regulations that function in terms of the legal framework, still we cannot say that our country is immune from the tendency of cyber crimes dramatically increased recently. This increase is due to the introduction of the Internet and electronic devices as a primary need in every field of social activity.

In Albania, the first Berisha's Government meeting, after the impeachment in September 2010, was opened with "E-KABINET" project. Through its, draft-decisions of the Council of Ministers does not come with paper from ministries to further prime minister, but they are provided in electronic form via a secure communication system.

\section{References}

AKEP, Autoriteti i Komunikimeve Elektronike dhe Postare, Historiku mbi zhvillimin e Post-Telekomunikacioneve web site: http://www.akep.al/sq/akep/historiku-i-ptt, accessed date 26.03.2013.

Ministria për Inovacionin Teknologjinë e Informacionit dhe të Komunikimit, Main page, website: http://www.mitik.gov.al/, accessed date 10.06.2013.

Portali unik qeveritar, Main page, web site: http://www.e-albania.al/, accessed date 10.06.2013

Agjensia Kombëtare e Shoqërisë së Informacionit, Main page, web site: http://akshi.gov.al/, accessed 10.06.2013.

Autoriteti Kombëtar për Certifikimin Elektronik, Main page, web site: http://www.akce.gov.al/, accessed date 10.06.2013.

Protik, ICT resurce center, Main page, web site: http://www.protik.org/, accessed dt.10.06.2013

USAID Albania, Njoftime për shtyp, USAID përmbyll Programin për Sigurinë Kibernetike në Shqipëri, Rifreskimi i fundit: 09 janar 2013 , web site: http://albania.usaid.gov/?fq=brenda\&m=shfaqart\&aid=577\&kid=26\&tit=USAID_Completes_Project_to_Support_Albania \%E2\%80\%99s_New_Cyber_Incident_Response_Agency\&gj=gj1, accessed date 10.06.2013.

Gazeta 55, Nr.151 (4216), e Premte 4 Qérshor 2010, Pollo: Nënshkrimi elektronik epokë e re për Shqipërinë, pg 14, web site: http://gazeta55.al/gazeta/04.06.2010.pdf, accesed date 10.06.2013. 